\title{
Modification of the availability of trace elements in contaminated mining soils by the use of additives
}

\author{
Modificación de la disponibilidad de elementos traza en suelos mineros \\ contaminados mediante la aplicación de enmiendas
}

\author{
Elvira Esteban ${ }^{1}$, Eduardo Moreno $^{1}$, Rodrigo Sepúlveda ${ }^{1 *}$
}

\section{RESUMEN}

El experimento se realizó en el invernadero de la Universidad Autónoma de Madrid-España. El muestreo fue en Bustarviejo, en el Valle Alto del Lozoya. La mina Mónica se sitúa a dos kilómetros al noreste de Bustarviejo, en las faldas de la Sierra de Guadarrama, en la cara sur. Estos suelos mineros son fuentes de metales pesados y su capacidad de retención y movilidad dependerá de las características del suelo. Para la realización del experimento se evaluaron distintas enmiendas minerales $\left(\mathrm{E} 33 \mathrm{P}, \mathrm{FeSO}_{4} \times 7 \mathrm{H}_{2} \mathrm{O}+\right.$ $\mathrm{CaCO}_{3}, \mathrm{KH}_{2} \mathrm{PO}_{4}$ y NPK) y orgánicas (compost) sobre la disponibilidad del elemento contaminante en diferentes tratamientos con la especie Lolium perenne como testigo vegetal. Las variables analizadas fueron: concentración total, concentración disponible y concentración total en plantas. Se encontraron diferencias significativas entre los distintos tratamientos, siendo el tratamiento con sulfato ferroso más carbonato cálcico eficaz en la reducción de la disponibilidad de elementos tóxicos. El diseño experimental que se utilizó es un análisis de varianza de un factor o one way.

Palabras claves: enmiendas, disponibilidad, fertilizantes, metales pesados, concentración.

\begin{abstract}
The experiment was performed in the Universidad Autónoma de Madrid-España. Sampling was performed in Bustarviejo, in the Valle Alto del Lozoya. The Mónica mine is located two km northwest of Bustarviejo, in the southern foothills of the Sierra de Guadarrama. Mining soils are sources of heavy metals; their capacity for retention and mobility depends on the characteristics of the soil. The experiment evaluated different mineral additives ( $\mathrm{E33P}, \mathrm{FeSO}_{4} \times 7 \mathrm{H}_{2} \mathrm{O}+\mathrm{CaCO}_{3} \mathrm{KH}_{2} \mathrm{PO}_{4}$ and NPK), and an organic additive (compost) on the availability of the contaminating elements using Lolium perenne as the plant indicator. The variables analyzed were total concentration, available concentration and total concentration in plants, which were analyzed using oneway analysis of variance. We found significant differences among the treatments; the treatment with ferrous sulfate plus calcium carbonate was the most efficient in reducing the availability of toxic elements.
\end{abstract}

Key words: soil additives, availability, fertilizers, heavy metals, concentration.

\section{Introduction}

The potential danger for the environment and for humans due to heavy metals in the soil comes from the metallic minerals (Abrahams, 2002; Adriano, 2001). Studies have reported high amounts of metals in soils affected by the oxidation of pyritic materials (Álvarez et al., 2003; Vásquez et al., 2006), a type of residue frequent in metal mines. Once metals accumulate, physicochemical factors condition the transfer of each metal from the solid to liquid phase; this causes differences in the availability of the metals to be absorbed by plant species, entering the food chain and finally causing the toxicity of the element. Heavy metals may reach critical levels in the soil; also the accumulation in plant tissues may produce an increase of the metals in the soil surface due to leaf fall, or create a way for the metals to enter in the trophic chain (Mertens et al., 2007; Unterbrunner et al., 2007).

Soils contaminated with heavy metals and metalloids frequently have low fertility, one of whose causes is the low organic metal content (Bernal et al., 2009). There also tend to be few roots for the grown of microbial biomass, low nutrient availability and poor structure, frequently with scarce or no plant cover (Bernal et al., 2009). This may lead to physical deterioration and possibly dissemination of the

1 Universidad Autónoma de Madrid, Facultad de Ciencia/Química Agrícola. Ciudad Universitaria de Cantoblanco - 28049 (Madrid-España)* Email: r.sepulveda.mella@gmail.com 
contaminants. Different additives may alleviate this problem, altering the distribution of heavy medals in the soil fractions and their availability for living organisms (Bernal et al., 2009).

\section{Materials and Methods}

Sampling was conducted in Bustarviejo in the high valley of Lozoya. The mine Mónica is located two kilometers from Bustarviejo, in the foothills of the Sierra de Guadarrama, in the south face. The coordinates mine U.T.M. are 30T X $=438552$, Y $=4524494$.

We sampled in two points, a non-contaminated control and a site with remains of mine tailings, in January, 2009. These points were chosen taking into account possible dispersion routes of heavy metals (tailings) and the possibly uncontaminated areas (control). The majority of these are located in the margins of the canyon and in the tailing zones.

In the greenhouse of the Universidad Autónoma de Madrid the soil was dried in the air for 7 days. Soil samples were sieved at $2 \mathrm{~mm}$ and homogenized for analysis. We analyzed organic matter, $\mathrm{pH}$, electrical conductivity (CE) and mineral elements (arsenic, cadmium, zinc, copper, lead and phosphorous), both total and available fractions.

T0 treatment used 100\% control soil; T1 used a mixture of $60 \%$ control soil and $40 \%$ tailings soil. Treatments T2-T6 also used the T1 mixture, but with additives. T2 used $18 \mathrm{~g}$ E33P; T3 used 43,92 $\mathrm{g}$ $\mathrm{FeSO}_{4} \times 7 \mathrm{H}_{2} \mathrm{O}+15,75 \mathrm{~g} \mathrm{CaCO}_{3}$ (calculations based on Lepp et al., 2002); T4 used $162 \mathrm{~g} \mathrm{KH}_{2} \mathrm{PO}$; 55 used $0,36 \mathrm{~g}$ NPK (these were calculated according to the nutritional needs of the test plant, Lolium perenne); $\mathrm{T} 6$ used $90 \mathrm{~g}$ compost (5\%). Treatments were prepared in $1.5 \mathrm{~L}$ pots; there were 4 replicas per treatment.

Pots were watered to field capacity for 3 weeks to equilibrate the soil (aging), in order to obtain more realistic conditions. After this period, the experiment began with homogeneous seedlings in three replicas of each treatment; the fourth was left without plants. Germination took approximately one week; the vegetative period lasted 6 weeks. During this period, pots were watered to field capacity.

To determine total element concentrations weighed $1 \mathrm{~g}$ of each of the soil samples. then added $6 \mathrm{ml}$ of distilled water, $6 \mathrm{ml}$ of nitric acid and $4 \mathrm{ml}$ of $\mathrm{H} 2 \mathrm{O} 2$ and was digested at $1.5 \mathrm{~kg} / \mathrm{cm}^{2}$ pressure for $30 \mathrm{~min}$ in an autoclave. Samples were then filtered
(Whatman $\mathrm{N}^{\circ} 38$ ) and filled up to $50 \mathrm{ml}$ (Wenzel et al., 2001; Wenzel et al., 2002). To determine available element concentrations, to $1.5 \mathrm{~g}$ of homogenized soil was added $20 \mathrm{~mL}\left(\mathrm{NH}_{4}\right)_{2} \mathrm{SO}_{4} 0.1 \mathrm{M}$ and distilled water. The mixture was agitated for 4 $\mathrm{h}$ at $180 \mathrm{rpm}$ at $20^{\circ} \mathrm{C}$ and then filtered (Whatman $\mathrm{N}^{\circ}$ 42) (Wenzel et al., 2001; Wenzel et al., 2002; Vázquez et al., 2007). For both methods blanks without soil were prepared. In the soil extracts we measured As, Cd, Zn, Cu, P and Mn using ICP-MS (inductively coupled mass spectrometry).

We analyzed the organic material of the soils by oxidation with potassium dichromate in the presence of sulfuric acid (MAPA, 1994). The excess of oxidant was evaluated with Mohr's salt (ferrous-ammonium sulfate) and the quantity of organic material was estimated by the amount of dichromate reduced. We analyzed the $\mathrm{pH}$ of the samples using a 1:2.5 soil-water suspension. We mixed $5 \mathrm{~g}$ of soil and $12.5 \mathrm{ml}$ distilled water. The sample was agitated for $10 \mathrm{~min}$ at $200 \mathrm{rpm}$ and left to stand for $30 \mathrm{~min}$, then measured with a pH meter (MAPA, 1994). The $\mathrm{pH}$ was determined in the same way at the end of the test, in the pots and in the pore water. The CE measurements of the samples were performed in a 1:5 soil water suspension. $5 \mathrm{~g}$ of soil were mixed with $25 \mathrm{ml}$ distilled water, then agitated for $1 \mathrm{~h}$ at $200 \mathrm{rpm}$ and filtered (Whatman $\mathrm{N}^{\circ} 38$ ), and finally measured with a conductivity meter. The CE of the pore water was determined similarly.

\section{Results and Discussion}

\section{Characterization of the soil and tailings}

Organic material (OM), Electrical conductivity (EC) and pH. Figure 1a shows the increase of EC in T1 (differences were significant) due to the content of metal and metalloid ions present in the contaminated soil. Figure $1 \mathrm{~b}$ shows that there were no differences in $\mathrm{pH}$ between the soils with and without tailings; soils were acid in both cases. Figure 1c shows significant differences due to a decrease in $\mathrm{OM}$ in $\mathrm{T} 1$ produced by the mixture with contaminated soil low in OM.

\section{Initial concentrations of total and available metals in $\mathrm{T0}$ and $\mathrm{T1}$}

The total initial concentrations of four metals in $\mathrm{T} 0$ and $\mathrm{T} 1$ are shown in Table 1 . There was an increase 


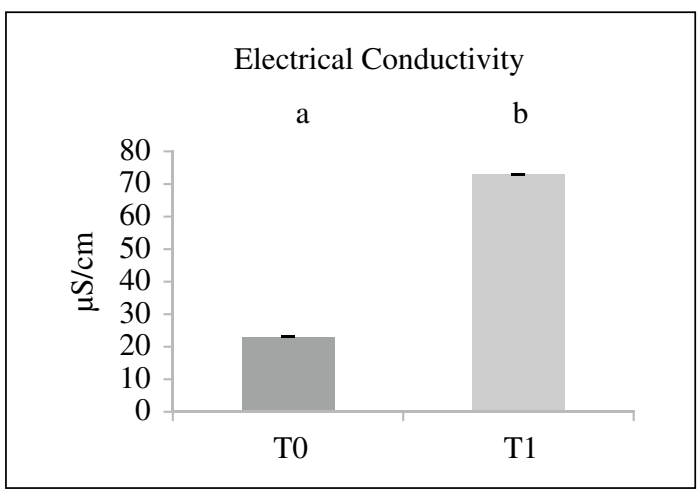

Figure 1a. Values of EC in soils. Mean \pm S.E. $(\mathrm{N}=5)$

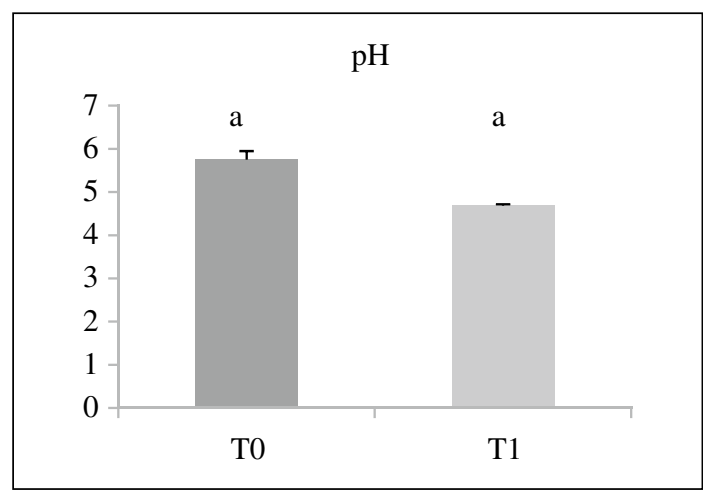

Figure 1b. $\mathrm{pH}$ for control and mixed soils. Mean \pm S.E. $(\mathrm{N}=5)$.

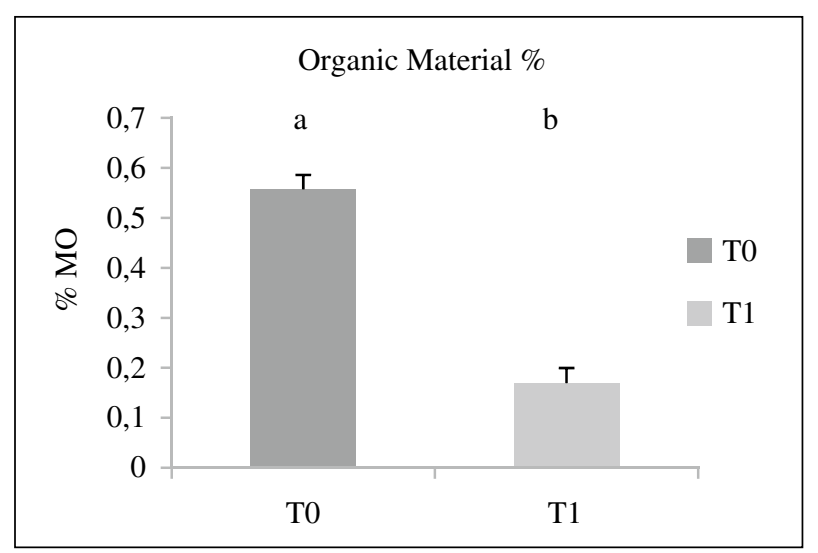

Figure 1c. Percentage of organic material in control and mixed soils. Mean \pm S.E. $(N=4)$

in the concentration of heavy metals and metals due to the mixture with tailings. Concentrations in T0 were below the reference levels of the Comunidad de Madrid, thus it is not considered a contaminated soil. However, the concentration of As in $\mathrm{T} 1$ was above the reference level. It is also clear that the available elements increased when mixed with tailings (Table 2).

Table 1. Initial concentrations of total elements $(\mathrm{mg} / \mathrm{kg})$ in T0 and T1. Mean \pm S.E. $(\mathrm{n}=3)$.

\begin{tabular}{lllll}
\hline & As & $\mathrm{Cd}$ & $\mathrm{Zn}$ & $\mathrm{Cu}$ \\
\hline T0 & $6.96 \pm 0.2$ & $0.07 \pm 0.015$ & $37.14 \pm 2.8$ & $6.40 \pm 0.1$ \\
T1 & $2721.73 \pm 93.05$ & $13.14 \pm 0.45$ & $3627.5 \pm 92.23$ & $798.50 \pm 11.1$ \\
\hline
\end{tabular}

Table 2. Initial concentrations of available elements $(\mathrm{mg} / \mathrm{kg})$ in T0 and T1. Mean \pm S.E. $(\mathrm{n}=3)$.

\begin{tabular}{lllll}
\hline & As & $\mathrm{Cd}$ & $\mathrm{Zn}$ & $\mathrm{Cu}$ \\
\hline T0 & $0.02 \pm 0.003$ & $0.02 \pm 0.0001$ & $0.02 \pm 0.019$ & nd \\
T1 & $6.92 \pm 0.2$ & $0.15 \pm 0.01$ & $4.21 \pm 0.31$ & $0.39 \pm 0.035$
\end{tabular}

nd: not detectable. 


\section{Changes in pH during plant growth}

$\mathrm{pH}$ values at the end of the study are shown in Figure 2. There was a significant increase in the $\mathrm{pH}$ of $\mathrm{T} 3$ due to the incorporation of $\mathrm{CaCPO} 3$ in the soil. The other treatments were not significantly different from $\mathrm{T} 1$. Comparison with the $\mathrm{pH}$ at the beginning of the study (Figure 1b) shows that there was no change in soil $\mathrm{pH}$.

\section{Concentration of toxic elements in the soil and plants}

\section{Concentration of As}

The total concentration of As in soil with tailings did not show differences between treatments (Figure 3a). However, the available As of T3 was significantly different from $\mathrm{T} 1,(3.68 \mathrm{mg} / \mathrm{kg})$; there was a decrease in the available As (Figure 3b). This was due to the formation of oxides of Fe in situ in soils, which reduces the bio-availability of As (Adriano, 2001), due to the co-precipitation and absorption of the element. The total concentration of As in the plants of T3 was significantly lower $(46 \mathrm{mg} / \mathrm{kg}$ ) than in T1 (Figure 3c). This effect may be attributed to a greater capacity to co-precipitate and retain As by the $\mathrm{Fe}$ oxides formed in situ, while in $\mathrm{T} 2$, in spite of the capacity of Fe oxides to retain As in liquid media, this was not effective in the soil. T6 $(4.75 \mathrm{mg} / \mathrm{kg})$ did not show a significant difference with $\mathrm{T} 1(3.68 \mathrm{mg} / \mathrm{kg})$ with respect to the concentration of available As (Figure 3c), however, it was significantly different from T1 (122.72 mg/ $\mathrm{kg}$ ) in the quantity in plant material (T6: $40 \mathrm{mg} / \mathrm{kg}$ ) (figure 3c). Adding compost to the soil probably increased the concentration of available As due to interchange with phosphates and organic complexes, and to the increase in the $\mathrm{pH}$ (Bernal et al., 2009). The increase of the concentration of $P$ in T6 $(0.34 \mathrm{mg} / \mathrm{kg})$ compared to $\mathrm{T} 1(0.02 \mathrm{mg} / \mathrm{kg})$ showed a decrease in As absorption (antagonism), since the phosphate-arsenate transporter has more affinity for $\mathrm{P}$ (Esteban et al., 2003). There was a much greater increase in As availability in T6 (compost) compared to $\mathrm{T} 4$ and $\mathrm{T} 5$, which received phosphate fertilizers and thus must have mobilized more As.

\section{Concentration of $\mathrm{Cd}$}

There was a significant decrease in the total $\mathrm{Cd}$ concentration in T6 compared to T1 (Figure 4a). The concentrations of available $\mathrm{Cd}$ were significantly different in $\mathrm{T} 2(0.11 \mathrm{mg} / \mathrm{kg})$ and $\mathrm{T} 3(0 \mathrm{mg} / \mathrm{kg})$. The concentration in $\mathrm{T} 3$ was even lower than the control T0 $(0.01 \mathrm{mg} / \mathrm{kg}$ ) (Figure 4b), which was also significant compared to T1. This effect in T3 may be attributed to the increase in $\mathrm{pH}$ due to the incorporation of $\mathrm{CaCO}_{3}$ and probably to the precipitation of $\mathrm{CdCO}_{3}$, the increase in $\mathrm{pH}$ controls the solubility of Cd (Alloway, 1995). There was also a decrease in the absorption of Cd by the plants in T3 $(0.28 \mathrm{mg} / \mathrm{kg}$ ) (Figure 4c), which had the lowest concentration of $\mathrm{Cd}$ in plant material and was significantly different from T1 and T2, 0.95 and $0.66 \mathrm{mg} /$ $\mathrm{kg}$, respectively. The difference between $\mathrm{T} 1$ and $\mathrm{T} 2$ was not significant, indicating that $\mathrm{Fe}$ oxides were not efficient in the co-precipitation of $\mathrm{Cd}$, leaving

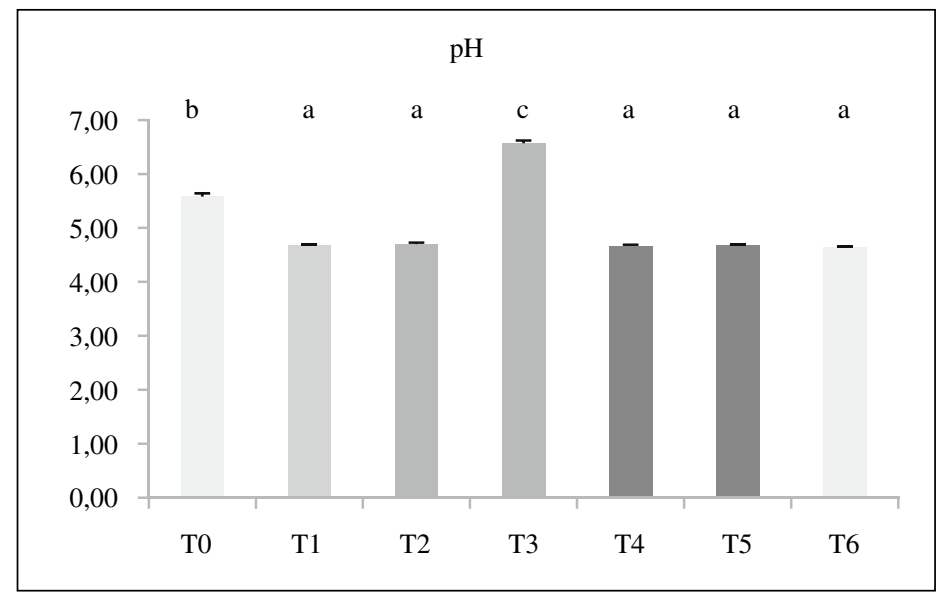

Figure 2. $\mathrm{pH}$ values at the end of the study Mean \pm S.E. $(n=3)$. 


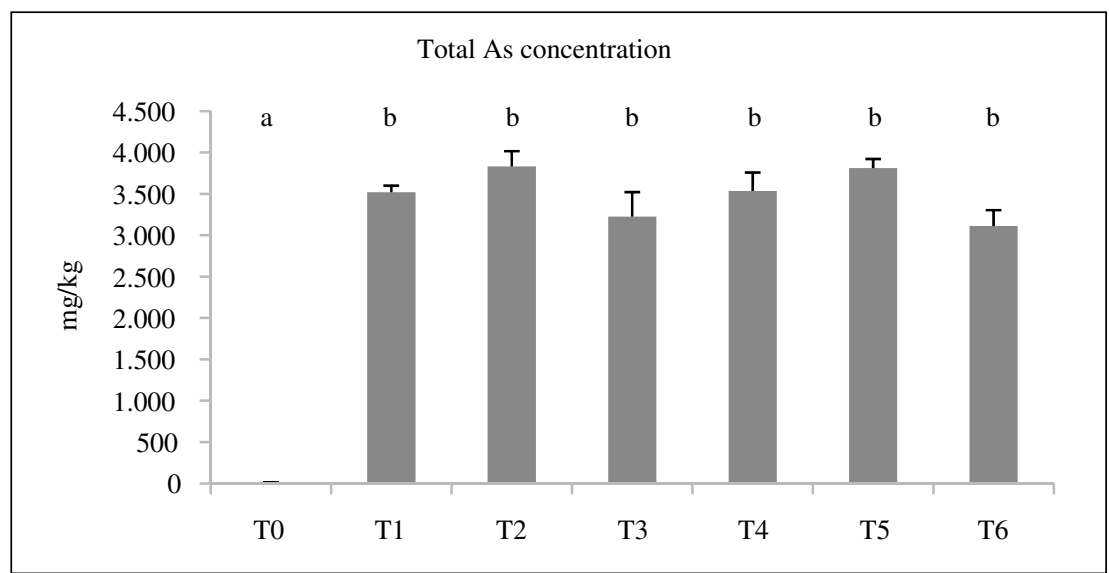

Figure 3a. Concentration of total As in the soil of the different treatments Mean \pm S.E. $(n=3)$.

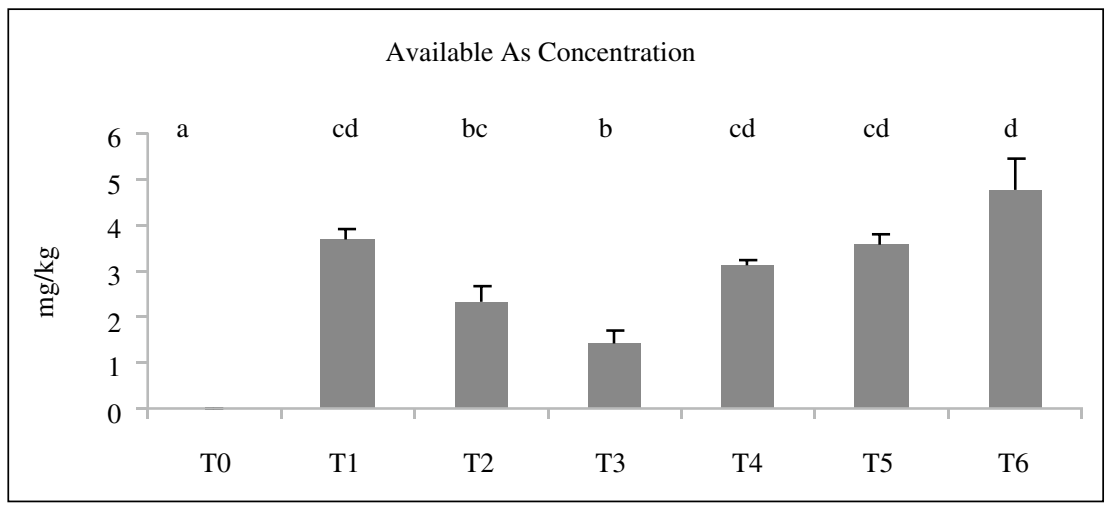

Figure 3b. Concentration of available As in the soil of the different treatments Mean \pm S.E. $(n=3)$

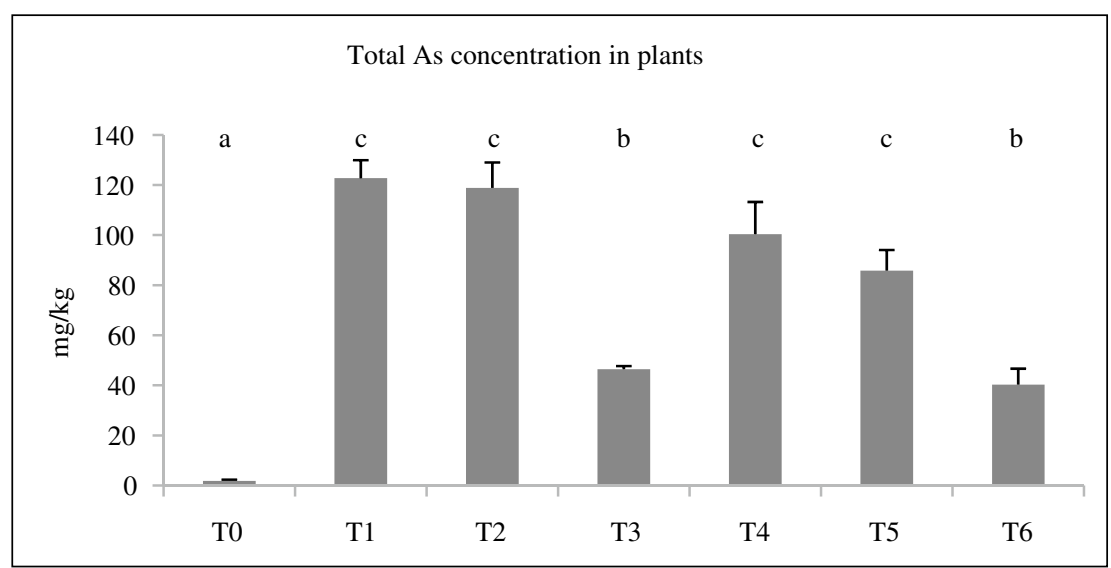

Figure 3c. Total As concentration in the above-ground plant material of the different treatments Mean \pm S.E. $(n=3)$

this element available in the soil. T6 had an elevated concentration of available $\mathrm{Cd}$ similar to $\mathrm{T} 1$ ( 0.10 and $0.11 \mathrm{mg} / \mathrm{kg}$, respectively) (Figure 4b); however, the concentration in the plant material was significantly lower in $\mathrm{T} 6(0.29 \mathrm{mg} / \mathrm{kg})$ than in $\mathrm{T} 1(0.95 \mathrm{mg} / \mathrm{kg})$ (Figure 4c). This effect was probably due to the concentration of $\mathrm{Mn}$ in the soil of T6 (30 mg/kg), significantly greater than that of $\mathrm{T} 1(15 \mathrm{mg} / \mathrm{kg})$, causing a $\mathrm{Cd} / \mathrm{Mn}$ antagonism which decreased the absorption of $\mathrm{Cd}$ by the roots and increased its concentration in plant material $(239 \mathrm{mg} / \mathrm{kg})$. Studies have demonstrated that the accumulation of $\mathrm{Cd}$ is 


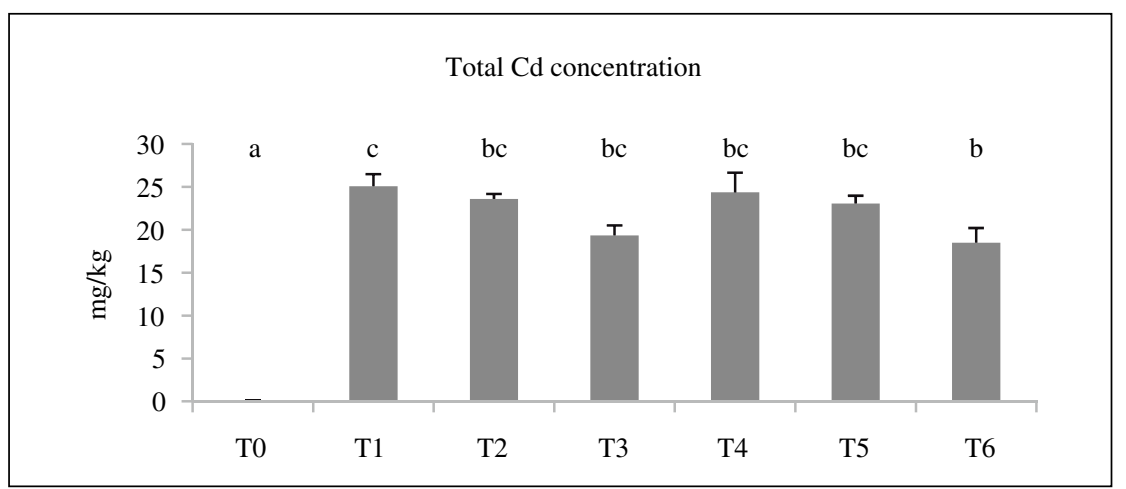

Figure 4a. Concentration of total soil AS in the different treatments distintos tratamientos Mean \pm S.E. $(n=3)$.

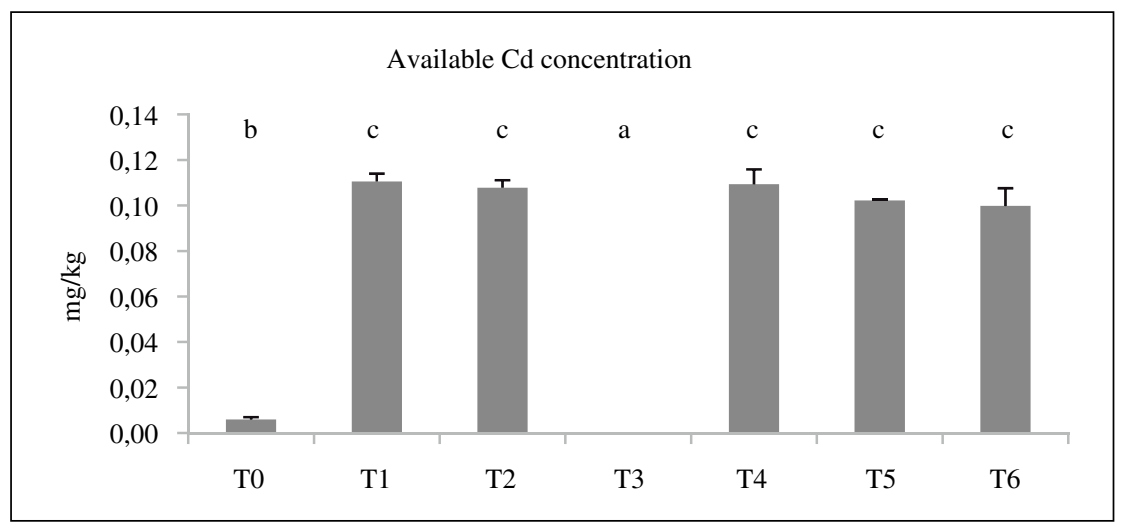

Figure 4b. Concentration of available $\mathrm{Cd}$ in soil in the different treatments Mean \pm S.E. $(n=3)$

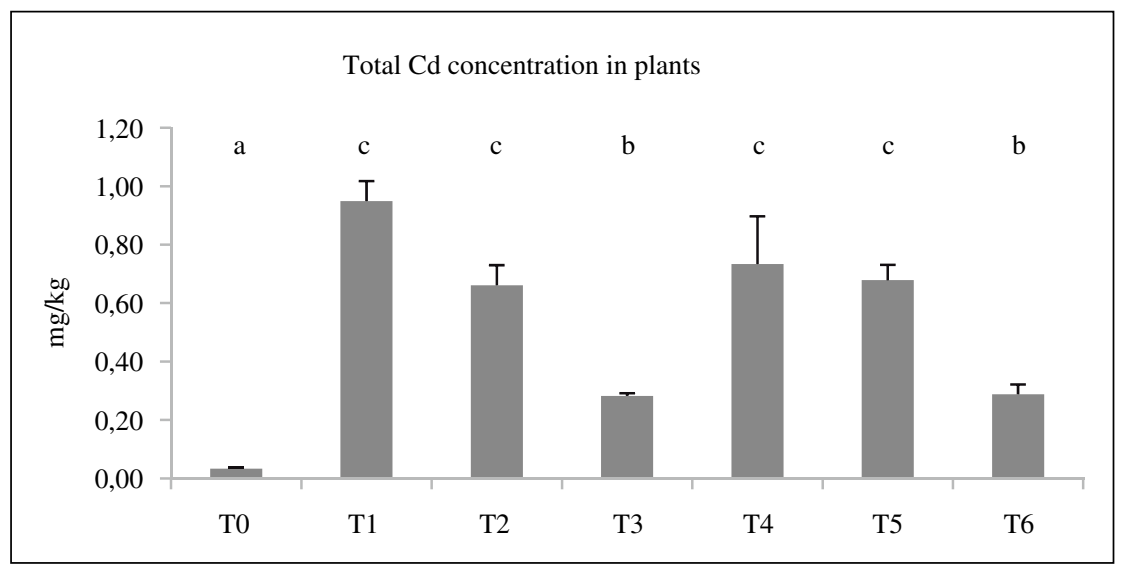

Figure. $4 c$. Total Cd concentration in plants of the different treatments Mean \pm S.E. $(n=3)$.

decreased in plant tissues when the concentration of Mn is greater (Hernández et al., 1998).

\section{Concentration of $\mathrm{Zn}$}

There were significant differences between $\mathrm{T} 3$ $(0.57 \mathrm{mg} / \mathrm{kg})$ and the other treatments with tailings
$(2.57-3.56 \mathrm{mg} / \mathrm{kg})$ in the amount of $\mathrm{Zn}$ available (Figure 5b); T3 immobilized the Zn best. Zn extraction decreases in calcareous soils (Adriano, 2001), and the availability of $\mathrm{Zn}$ diminishes in calcareous soils with high $\mathrm{pH}$; it is absorbed by $\mathrm{CaCO}_{3}$ forming nearly insoluble compounds such as $\mathrm{Zn}(\mathrm{OH})_{2}$ and $\mathrm{ZnCO}_{3}$ (Marschner, 1995), and 


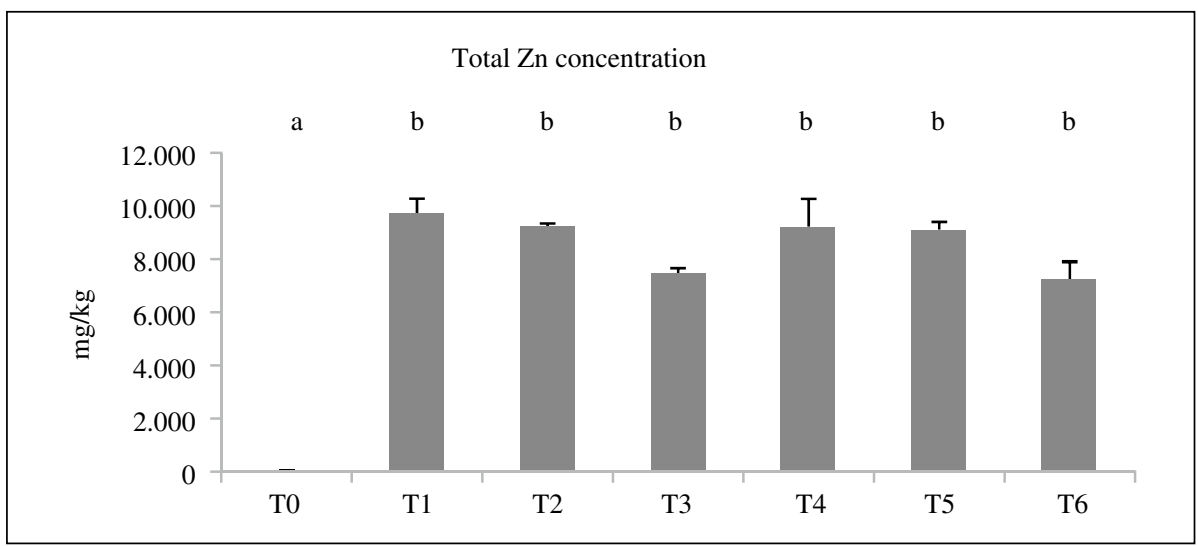

Figure 5a. Total concentration of $\mathrm{Zn}$ in the soil of the different treatments. Mean \pm S.E. $(\mathrm{n}=3)$.

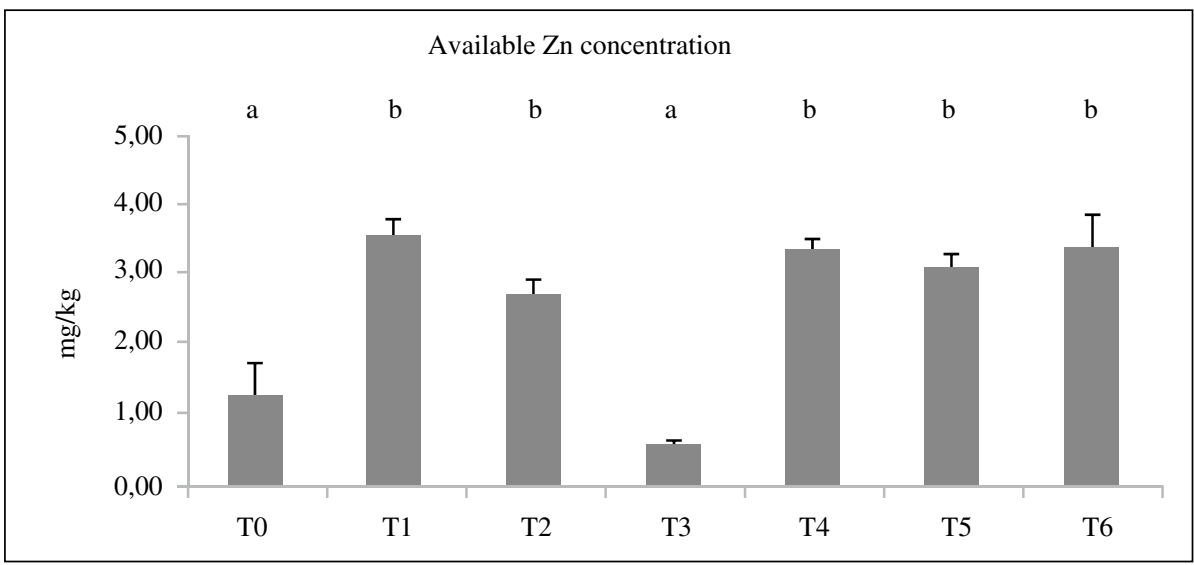

Figure 5b. Concentration of $\mathrm{Zn}$ available in the soil of the different treatments. Mean \pm S.E. $(\mathrm{n}=3)$.

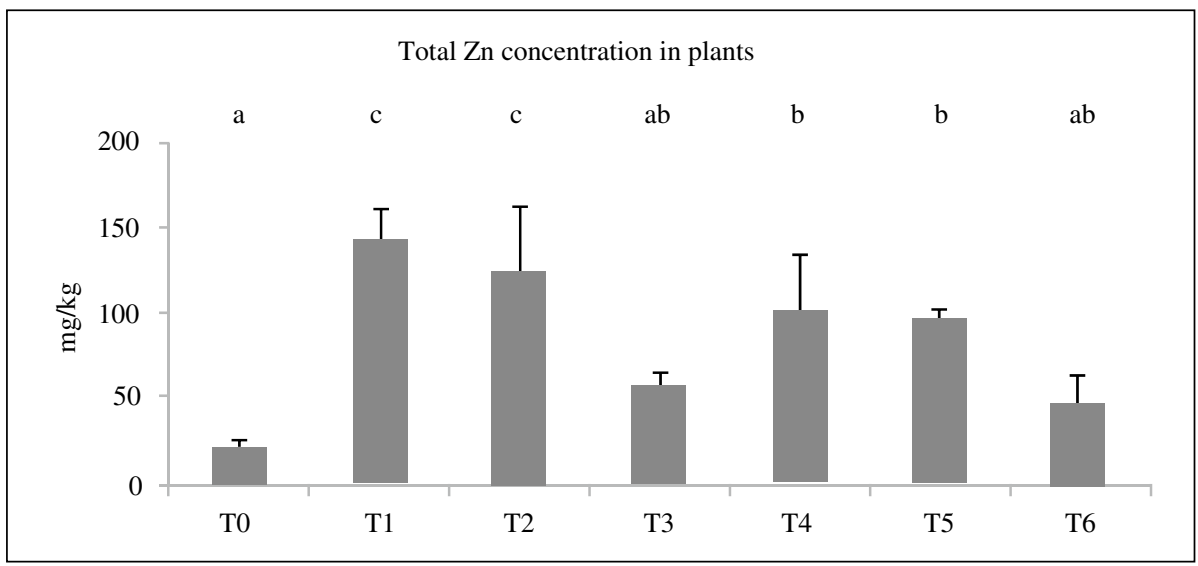

Figure 5c. Concentration of $\mathrm{Zn}$ in the plants of the different treatments. Mean \pm S.E. $(\mathrm{n}=3)$.

probably the co-precipitation by iron oxides decreased the concentration of the element available. Thus the absorption by plants was significantly reduced in T3 (58 mg/kg) compared to T1 (143.53) (Figure 5c). The difference between $\mathrm{T} 1$ and $\mathrm{T} 2$ was not significant for plant material, thus the synthetic iron oxides used to purify the water were not efficacious in retaining $\mathrm{Zn}$, leaving this element available in the soil. There was also no difference in the concentration of available $\mathrm{Zn}$ between T4 
and T5 (Figure 5b). However, the concentration in plant material was significantly different between them, probably due to the dilution of the element in the greater growth of the plants (Figure 5c). T6 was not different from $\mathrm{T} 1$ in the concentration of available $\mathrm{Zn}$ (3.42 and $3.56 \mathrm{mg} / \mathrm{kg}$ respectively) (Figure $5 b$ ), however, the total plant concentration of Zn was (significantly) much lower in T6 (48.1 mg/

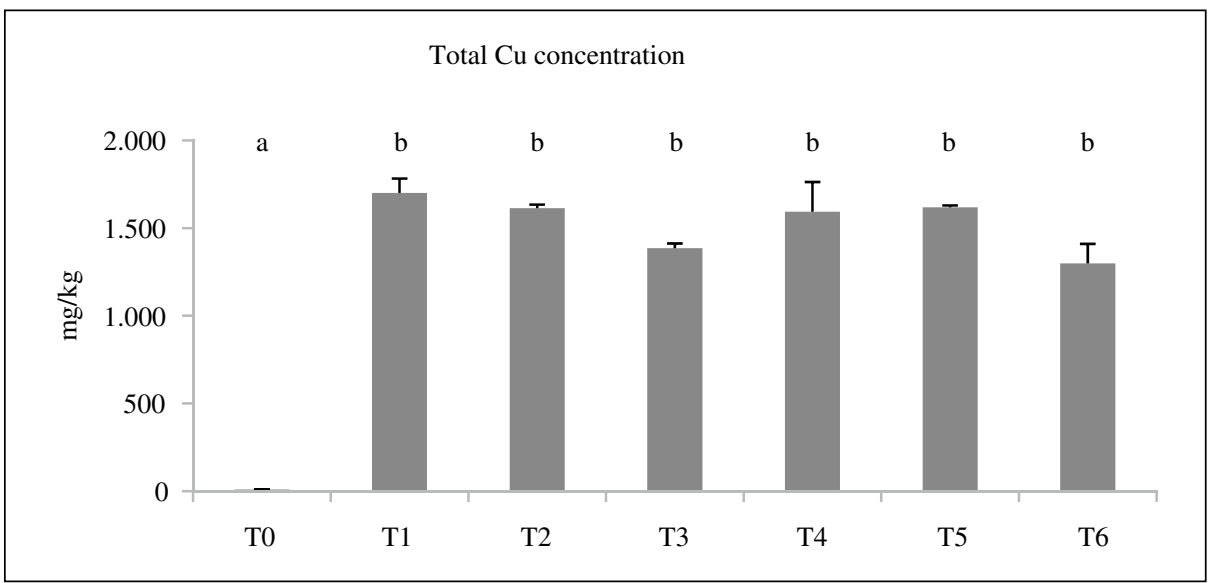

Figure 6a. Total $\mathrm{Cu}$ concentration in the soil of the different treatments, Mean \pm S.E. $(n=3)$.

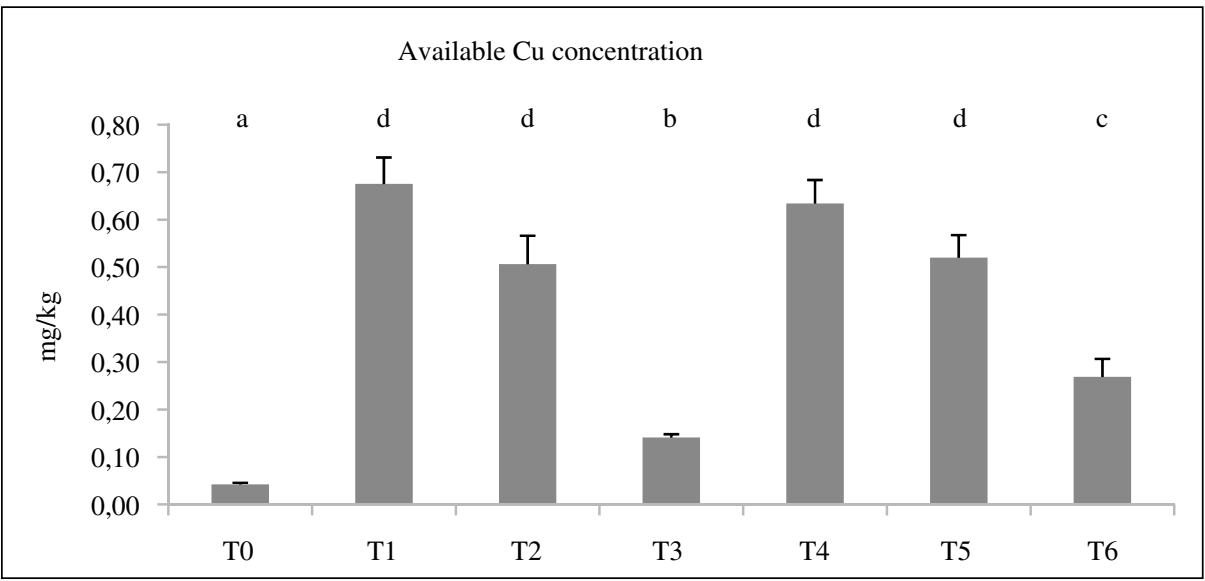

Figure $6 b$. Available $\mathrm{Cu}$ concentration in the soil of the different treatments, Mean \pm S.E. $(n=3)$.

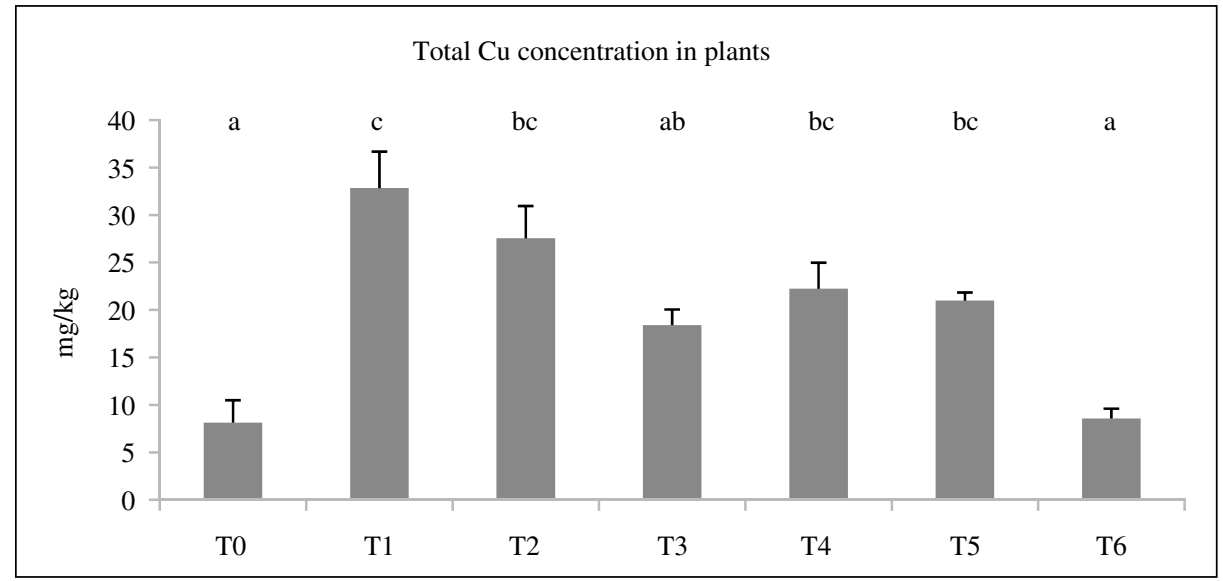

Figure 6a. Total $\mathrm{Cu}$ concentration in the soil of the different treatments, Mean \pm S.E. $(n=3)$. 
$\mathrm{kg}$ ) than in $\mathrm{T} 1(143.53 \mathrm{mg} / \mathrm{kg}$ ) (Figure 5c). High concentrations of Mn in T6 $(29.88 \mathrm{mg} / \mathrm{kg})$ induced the low absorption of $\mathrm{Zn}$ by plants, produced by a Zn/Mn antagonism Mn (Marschner, 1995) and an increase of $\mathrm{Mn}$ in the plants.

\section{Concentration of $\mathrm{Cu}$}

There were significant differences of available $\mathrm{Cu}$ in $\mathrm{T} 3$ compared to the other treatments (Figure $6 \mathrm{~b}$ ), indicating a high immobilization of this element $(0.14 \mathrm{mg} / \mathrm{kg})$. Cu deficiency is found in basic soils, decreasing its bio-availability (Marschner, 1995); the presence of iron oxides also controls the absorption of $\mathrm{Cu}$ (Adriano, 2001), probably by its co-precipitation as occurs with $\mathrm{Zn}$ and $\mathrm{Cd}$. Khan and Jones (2008) reported that the application of lime reduced the availability of $\mathrm{Cu}$ and $\mathrm{Zn}$ for plants. The difference between $\mathrm{T} 1$ and $\mathrm{T} 2$ was not significant for available $\mathrm{Cu}$, thus the synthetic iron oxides used to purify the water were not efficient in retaining $\mathrm{Cu}$, leaving this element available in the soil. The total $\mathrm{Cu}$ concentration in plants was significantly different between T3 and T1 (18.40 and $32.84 \mathrm{mg} / \mathrm{kg}$ respectively) (Figure 6c). There was a significant difference in the available $\mathrm{Cu}$ (Figure $6 \mathrm{~b}$ ) between T6 and T1 $(0.27$ and $0.68 \mathrm{mg} /$ $\mathrm{kg}$ respectively); its concentration in soil decreased with compost. Stevenson and Fitch (1981) reported the formation of $\mathrm{Cu}-\mathrm{MO}$ complexes in soil, being retained in the matrix, especially with humic acids, which also decreased the concentration in plants
(Figure 6c), with a significant difference compared to T1 (8.57 and $32.84 \mathrm{mg} / \mathrm{kg}$, respectively).

\section{Biomass and visual symptoms}

There were significant differences in the aerial biomass of Lolium perenne between $\mathrm{T} 3$ and $\mathrm{T} 6$ with respect to the rest of the treatments and the control. During the 6 weeks of vegetative growth there was a tendency to less biomass in treatments $\mathrm{T} 1, \mathrm{~T} 2, \mathrm{~T} 4$ and $\mathrm{T} 5$.

\section{Conclusions}

In terms of the use of additives based on iron oxides to reduce the availability of contaminant soil elements, the treatment with ferrous sulfate and calcium carbonate reduced efficiently the availability of toxic elements and thus the toxicity of the tailings, allowing plant grown comparable with the control. However, treatment with ferric oxide (E33P) was not effective in reducing bio-availability. The use of compost did not reduce the bio-availability of toxic elements efficiently, although it reduced the concentrations of elements in the plants and allowed more vegetative growth than the control, thus it might cause some mobilization of toxic elements in the soil. The additives based on phosphate did not have significant effects in the mobility of the toxic elements or en plant growth. Among the tested soil additives, T3 (calcium carbonate and ferrous sulfate) was the most efficient.

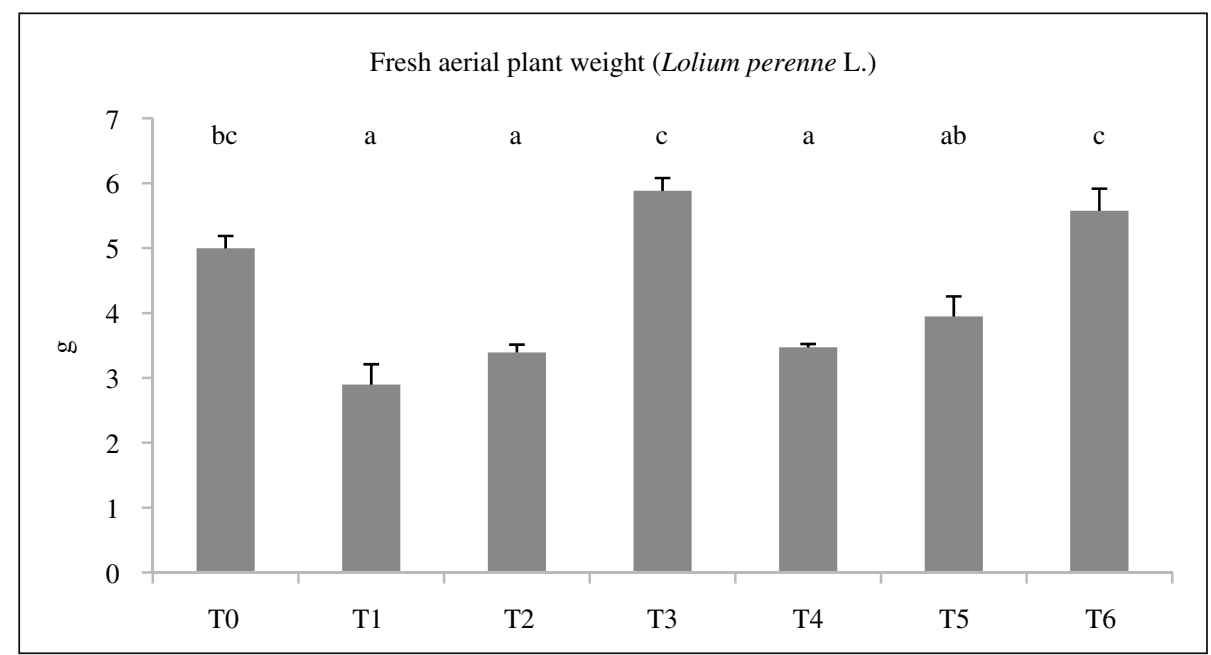

Figure. 7. Fresh aerial plant weight at the end of the experiment. Mean \pm S.E. $(n=3)$. 


\section{Literature Cited}

Abrahams. P.W.

2002 Soils: their implications to human health, Sci. Tot. Environ. 291, 1-32

Adriano D.C.

2001 Trace elements in terrestrial environments. Biochemistry, Bioavailability, and Risk of Metals, $2^{\text {nd }}$ ed., Springer, New York, 2001.

Alvarez, E.; Fernández-Marcos, M.L.; Vaamonde, C.; Fernández-

Sanjurjo, M.J.

2003 Heavy Metals in the dump of an abandoned mine in Galicia (NW Spain) and in the spontaneously occurring vegetation, Sci. Tot. Environ. 313, 185-197

Alloway, B.J.

1995 Heavy Metals in Soils. Soil processes and the behaviour of metals. 11-37.

Bernal, M.P.; Clemente, R.; and Walker, D.J.

2009 Interactions of heavy metals with soil organic matter in relación to phytoremediation. Phytoremediation: The Green Salvation of the World. 109-129

Creger T.L.; Peryea, F.J.

1994 Phosphate fertilizer enhances arsenic uptake by apricot liners grown in lead-arsenate-enriched soil, Hort. Science $29,(2), 88-92$.

Cunningham, S.D.; Berti, W.R.

1997 Phytoextraction or phytostabilization: technical, economic, and regulatory considerations of the soil-lead issue. In Proc. 4th international Conf. Biogeochemistry of Trace Elements, Terry, N., ed.

Esteban E.; Carpena, R.O.; Meharg, A.A.

2003 High-affinity phosphate/arsenate transport in white lupin (Lupinus albus) is relatively insensitive to phosphate status. New Phytologist. 158: 165-173.

Kobayashi, J.

1979 In F.W. Oehme, ed. Toxicity of Heavy Metals in the Environment, part 1. Marcel Dekker, New York.
MAPA (Ministerio de Agricultura, Pesca y Alimentación) 1994 Métodos oficiales de análisis: Tomo III. Secretaría General Técnica. Madrid, Spain.

Marshner, $\mathrm{H}$.

1995 Mineral nutrition of higher plants. Function of mineral nutrients: micronutrients "Zn". Academic Press. London. $889 \mathrm{pp}$.

Mertens J.; Vervaeke, P.; De Schrijever, A.; Luyssaert, S.

2007 Metal uptake by young trees from dredged brackish sediment: limitations and possibilities for phytoextraction and phytostabilisation, Sci. Tot. Environ. Pollut. 145, 121-130.

Moreno-Jiménez, E.; Peñalosa, J.; Manzano, R.; Carpena-Ruiz,

R.; Gamarra, R.; Esteban, E.

2008 Heavy metals distribution in soils surrounding an abandoned mine in NW Madrid (Spain) and their transference to wild flora.

Unterbrunner, R.; Puschenreiter, M.; Sommer, P.; Wieshammer,

G.; Tlustos, P.; Zupan, M.; Wenzel, W.W.

2007 Heavy metals accumulation in trees growing on contaminated sites in Central Europe, Environ. Pollut. 148, 107-114.

Vázquez S.; Moreno, E.; Carpena, R.O.

2008 Bioavailability of metals and As from acidified multicontaminated soils: validation of several extraction methods by lupin plants. Environ. Geo. Health, 30:193-198.

Wenzel, W.W.; Brandstetter, A.; Wutte, H.; Lombi, E.; Prohaska,

T.; Stingeder, G.; Adriano, D.C.

2002 Arsenic in field-collected soil solutions and extracts of contaminated soils and its implication to soil standards. Journal of Plant Nutrition and Soil Science. 165: 221-228.

Wenzel, W.W.; Kirchbaumer, N.; Prohaska, T.; Stingeder, G.; Lombi, E.; Adriano, D.C.

2001 Arsenic fractionation in soils using an improved sequential extraction procedure. Anal Chim Acta. 436: 309-323. 